\title{
The Winner Takes it All: Revisiting the Effect of Direct Democracy on
}

\section{Citizens' Political Support}

\author{
Sofie Marien ${ }^{1,2}$ and Anna Kern ${ }^{1}$ \\ ${ }^{1}$ University of Leuven, Belgium \\ ${ }^{2}$ University of Amsterdam, The Netherlands
}

sofie.marien@kuleuven.be

Political Behavior, forthcoming. The final publication is available at link.springer.com via http://dx.doi.org//10.1007/s11109-017-9427-3.

(C) Political Behavior

\begin{abstract}
Despite the strong theoretical expectations about the beneficial effect of direct democratic instruments on citizens' political support, the empirical evidence is scarce and inconsistent. We add to this literature by studying the effect of the use of a direct democratic process on citizens' political support and its underlying causal mechanism. Using a unique research design that combines a strong test of causality with a high level of ecological validity, we surveyed inhabitants of a Belgian neighborhood that held a local referendum and a comparison group (i.e. inhabitants of a comparable neighborhood without referendum) before and after the referendum $(n=1,049)$. Using difference-indifferences analysis and first difference regression analysis, we show that in line with our expectations the increase in political support following the referendum is not driven by involvement or procedural fairness perceptions but by an increase in support levels among the winners of the decision. Moreover, despite the contested nature of the issue, losers' level of political support did not decrease significantly after the result of the referendum was announced.
\end{abstract}




\section{Introduction}

Declining engagement in elections and political parties as well as widespread distrust in political institutions and actors have raised concerns about a democratic legitimacy deficit in advanced democracies (Blais and Rubenson 2013; della Porta 2013; Norris 2011; van Biezen et al. 2012). To address citizens' novel participation preferences and to foster political support, proposals for more direct citizen involvement in the political decision-making process have been launched increasingly (Scarrow 2001; Smith 2009; Qvortrup 2017). Direct participation in policy-making through e.g. a referendum seems to align well with citizens' participation preferences as it allows them to vote on specific issues, consumes little time and does not entail long-term commitments. Exactly these characteristics are considered important elements of the participation preferences of contemporary citizens (Stolle and Hooghe 2004). In effect, support for direct democracy is widespread among contemporary citizens (Leininger 2015).

Especially at the local level, political decision-making processes that include elements of direct democracy are gaining popularity (Olken 2010). In contrast to the national level, traditional party politics is generally less at play at this level and decisions relate more closely to citizens' everyday life increasing engagement with the issue and citizens' ability to make an informed choice (Bryan 2003; Oliver et al. 2012). In effect, the local level offers good opportunities to engage citizens in the political decision-making process. Therefore, the introduction of more extensive opportunities for direct citizen involvement in (local) political decision-making processes has the potential to mobilize citizens to engage, thereby, counteracting the current decline in political participation (Dalton and Welzel 2014).

Drawing on procedural fairness and participatory democracy theory, scholars have theorized that direct involvement will also foster citizens' political support because eligible citizens value voice 
and influence in political decision-making processes (Bowler \& Donovan 2002; Pateman 1970; Tyler 2006). Despite these strong theoretical claims and a number of prominent empirical studies on the effects of direct democratic processes (e.g. Smith and Tolbert 2004; Smith 2002; Tolbert et al. 2003), empirical studies on its effect on citizens' political support remain scarce and the findings are inconsistent (Leininger 2015). Most empirical studies have relied on cross-sectional data to study whether citizens' support is higher in states or cantons in which direct democratic rights or experiences are more extensive (e.g. Bauer and Fatke 2014; Dyck 2009; Hug 2005; StadelmannSteffen and Vatter 2012; Voigt and Blume 2015). These studies provide inconsistent findings with positive, non-significant and negative relationships between direct democracy on the one hand, and variables such as political trust and democratic satisfaction on the other hand. Moreover, empirical evidence on cases that have little experience with this type of decision-making processes is scarce.

Despite all its merit, as with all cross-sectional designs, we cannot draw strong causal conclusions from these predominantly cross-sectional studies. For instance, the causal claim that extensive use of direct democratic rights in Swiss cantons leads to distrust in local political authorities could easily be reversed as distrust in local authorities is likely to stimulate citizens to push for a citizen initiative. The few experimental studies, on the other hand, allow for stronger causal claims, but it is uncertain whether these results can be generalized to real-life involvement. It is also unclear whether the results from this particular set of cases in which experience with direct democratic processes is abundant can be generalized to cases in which a direct democratic process is used on an ad hoc basis. While the latter are increasingly gaining popularity.

Therefore, the aim of this study is to enhance our understanding of how and why direct democratic processes influence citizens' political support. In particular, we analyze the effect of the use of a direct democratic instrument at the local level on local political support within a context in which 
experience with direct democratic decision-making is limited. In this study, we focus on the shortterm effects. We argue that granting citizens a vote in a specific decision-making process will increase political support levels over the short term. However, this increase does not result from an increase in perceived fairness or perceived influence on the decision-making process as most previous studies theorized. We argue that changes in political support are driven by outcome favorability i.e. by an increase in support among the winners of the direct democratic process, who by definition make up the majority. Therefore, the ad hoc use of a direct vote to make a political decision is not enough to boost political support across the population. To test this argument, we developed an original research design and gathered panel data in two comparable Belgian neighborhoods (with and without referendum). This design enables us to conduct a stronger causal test than previous cross-sectional studies with higher levels of ecological validity than experiments.

In the remaining of this article, we first briefly review the literature on direct democracy and citizens' opinions toward the political system and expand on our argument. Subsequently, we describe the context of the study, the research design and its results. Finally, the results and its implications are summarized in the conclusion.

\section{The effect of direct democratic instruments on citizens' political support}

One of the most prominent theoretical frameworks on the beneficial effects of citizen involvement in political decision-making processes is participatory democracy theory. Theorists have argued that engagement in political decision-making processes leads to the development and nurturing of more positive democratic characteristics, such as community-mindedness and political support (Barber 2003; Pateman 1970; Polletta 2002). Political support can be conceptualized as a multidimensional concept that includes satisfaction with policies as well as a more general evaluation of how well a political system, its institutions or authorities are living up to citizens' normative expectations 
(Easton 1965; Miller and Listhaug 1990). In line with the seminal work of David Easton (1965) we study different indicators of political support including satisfaction with local policy, trust in local political authorities and the evaluation of how well democratic principles are upheld in the municipality.

Participatory democracy theorists make a case for a political system which includes extensive possibilities for citizens' participation in the making of decisions. The extensive use of direct democratic instruments offers citizens democratic training and could increase the responsiveness of policymakers. Citizens can, for instance, put an issue on the agenda or veto a decision by collecting signatures of fellow citizens. In addition to the effective use of these direct democratic instruments, its availability can already give citizens the feeling that they could have a say. As a result, the availability and use of direct democratic instruments are both theorized to lead to more political support over the long term. However, scholars have also used this framework to theorize about the short-term effects of the ad hoc inclusion of citizens in political decision making processes on political support. This article focuses on these expected short-term effects of the use of direct democratic instruments. In the literature there are two prominent causal mechanisms that aim to explain these effects.

First, direct democratic processes are expected to foster political support by increasing the perceived fairness of the decision-making process among citizens. Citizens evaluate a decision-making process in which ordinary citizens have a voice as more fair than a purely representative process (De Cremer and Tyler 2007; Esaiasson et al. in press; Skitka and Wisneski 2012). Because citizens value fairness in general and fair decision-making processes in particular (Fehr and Schmidt 1999; Tyler 2011), political support is expected to increase when direct democratic instruments are used to make political decisions. Procedural fairness theory argues that fair procedures can even mitigate the 
negative effect of unfavorable decisions (e.g. Tyler 2011; Grimes 2006). Citizens might not get the preferred outcome but because they had a voice in the process, they consider the process as fair which in turn fosters their political support. Likewise, within democratic theory election losers are expected to consent to unfavorable election results if the election process can be considered to be free and fair (e.g. Przeworski 1991). ${ }^{1}$

Second, direct democratic processes are expected to foster political support because they increase the perceived influence on political decisions among citizens (Ulbig 2008; Stadelmann-Steffen and Vatter 2012). Through direct democratic decision-making citizens get an "occasional voice in government" (Bowler and Donovan 2002, p. 376). The feeling of being able to make decisions on particular issues themselves and being listened to, can strengthen citizens' perception of influence on the political decision-making process and more broadly feelings of self-determination and immediate influence on one's society and living conditions. Because of these beneficial effects, a direct vote is expected to increase political support. These effects are expected regardless of the favorability of the outcome. Even if they did not get what they want, citizens had the opportunity to influence the decision-making process and their living conditions. The increase in self-expressive values in the past decades is likely to have even increased this effect as the importance contemporary citizens attach to influence in the political decision-making process has heightened (Dalton and Welzel 2014).

Despite these strong theoretical claims, empirical evidence on the effects of direct democratic instruments on political support is limited and the available results are mixed (Leininger 2015).

\footnotetext{
${ }^{1}$ In the empirical literature citizen involvement, also using direct democratic processes, is often theorized as more fair than purely representational processes. Yet we could question whether this reasoning holds for democratic minorities. While scholars have looked into the nature of the outcome of direct democratic processes and whether they harm minorities (Donovan \& Bowler 1998; Haider-Markel et al. 2007; Vatter \& Danaci 2010), empirical evidence on how minorities evaluate these procedures is lacking.
} 
Moreover, most studies are focused on long-term effects and cases with extensive experience with direct democratic processes. On the one hand, empirical studies show that citizens who live in contexts in which citizens are more directly involved in decision-making processes believe more strongly that the government is responsive to their demands (Bowler and Donovan 2002; Hero and Tolbert 2004; Mendelsohn and Cutler 2000; Smith and Tolbert 2004) and are more satisfied with how democracy is working (Stadelmann-Steffen and Vatter 2012). Experiments in Sweden also showed that personal involvement through direct voting increases legitimacy beliefs among high school students on the short-term (Esaiasson et al. 2012; Persson et al. 2013). A field experiment in Indonesia revealed that satisfaction with the political process was higher following a direct vote process compared to a representative process in which citizens were consulted (Olken 2010). On the other hand, Gilens, Glaser, and Mendelberg (2001) cannot find a direct effect of ballot propositions on political attitudes. The absence of a direct effect between direct democratic procedures on the one hand and internal and external efficacy on the other hand is also ascertained by Schlozman and Yohai (2008) and by Dyck and Lascher (2009). While most studies document a positive association between the availability of direct democratic instruments and political support, the empirical evidence on its use is more mixed (Bauer and Fatke 2014; Kern 2017; Stadelmann-Steffen and Vatter 2012). Therefore, this empirical investigation is focused on the effect of the use of a referendum to make a decision on a contested local issue on local political support. In line with the dominant idea in the literature that citizen involvement will increase political support, we expect that:

H1: Using a referendum to make a political decision will increase citizens' political support.

Personal involvement is often considered a critical condition to its transformative effects, thereby, different effects are predicted depending on whether people cast a vote (e.g. Barber 2003; Smith 
2002). In particular, we expect:

H2: Political support increases among people that vote in a referendum compared to people that do not vote.

Empirical evidence on the causal mechanisms underlying these effects is scarce and its results are mixed (e.g. Leemann \& Wasserfallen 2016). Therefore, this study also aims to increase our understanding of how and why a direct democratic process affects political support on the shortterm.

The causal mechanism

Contrary to the bulk of the studies claiming that procedural fairness or increased influence drive the changes in political support following the use of a direct democratic process, we argue that outcome favorability is the key driver of change. Due to the polarizing nature of direct democratic processes, voters of the outcome that received the majority of the votes gain more utility from direct democratic processes than voters who opted for the minority option. Thereby decision winners are expected to change their opinions' toward the political system that granted their wishes (Anderson and LoTempio 2002; Lago and Martínez in press; Morrell 1999). Decision losers are able to have their say over the outcome, yet their loss in this polarizing process inhibits a positive change in opinion toward the political system. Given that winners are by definition in the majority, on the aggregate an increase in citizens' political support will occur if winners' support increases and losers' support remains stable.

This is in line with adherents of liberal democracy theory who consider the protection of one's interests as the main function of political participation (della Porta 2013). Following this logic, citizens participate because they want to ensure that representatives do not take measures that run 
against their interests (Verba et al. 1995). This kind of reasoning is also central within instrumental voting theory (Downs 1957; Geys 2006). In effect, direct democratic instruments provide citizens an extra opportunity to propose policies and to interfere if decisions are taken that threaten citizens' interests (Wagschal 1997; Altman 2014). In sum, this causal mechanism is not focused on the effects of the opportunity to voice one's interests or to influence the process but on the outcome of the process (Arnesen 2017), particularly the favorability of the option that received the majority of the votes. Moreover, the evaluation of the fairness of a decision-making process has even been argued to be shaped by outcome favorability (Shane et al. 2011).

An aggregate winner-loser gap in political support can emerge through different trends. Election scholars have argued that voting for a party that enters government will heighten political support, while if the party does not enter government this will depress political support. Losers gain less utility from the system, losing generates negative emotions and cognitive dissonance might motivate losers to adjust their political support (Anderson et al. 2007; Esaiasson 2011). As people tend to react more strongly to bad compared to good events, political support among election losers can even decline more strongly than it increases among winners (e.g., Ito et al. 1998; Pierce et al. 2016; Soroka 2014). Democratic theorists, however, argue that losers will retain their political support when basic democratic conditions are met such as free and fair elections, respectful treatment of losers and a fair chance of winning in a next occasion (Dahl 1989; Przeworski 1991). Yet, these trends can still cause a support gap following a rise in winners' political support and stability in losers' political support.

Empirical studies have repeatedly documented a gap in political support based upon whether voters supported the party that entered government after the election (e.g. Anderson et al. 2007; Craig et al. 2006; Marien 2011). Less is known on the trends in winners' and losers' political support that 
create this gap. A noteworthy exception is the study of Essaisson (2011) which shows that - when elections are reasonably well executed - winners gain support while losers retain their support. To date, it is unclear whether these findings from election studies can be generalized to a direct vote. In effect, the dominant frameworks to think about the effects of direct democratic instruments on support are participatory democracy theory and procedural fairness theory which do not attribute an important role to outcome favorability.

The standard methodological approach focuses on the relation between direct democratic instruments and aggregate levels of political support. This approach limits an in depth study of the causal mechanism. It is unclear how changes in support among voters of the different options (i.e. winners and losers) and non-voters shape the documented aggregate changes. A recent pioneering study addresses this lacuna and shows that outcome favorability is indeed critical in the decision acceptance of the outcomes of a direct democratic process (Esaiasson et al. in press). Based on 28 field and vignette experiments in Sweden, outcome favorability was found to affect decision acceptance in a direct democratic process directly as well as indirectly by coloring perceptions of procedural fairness (Esaiasson et al. in press, p. 31). However, the question how outcome favorability within a direct democratic process affects citizens' political support remains open to debate.

Therefore, in this study, we aim to contribute to this flourishing literature by investigating the effects of the use of a referendum at the local level on local political support on the short term. We aim to test the causal mechanism of outcome favorability and the two frequently proposed alternative explanations (perceived fairness and influence). Does the use of a direct democratic process influence political support because of the beneficial effects of its process characteristics or the nature of its outcome? Today in most democracies the use of direct democratic processes is still relatively 
scarce (Leininger 2015), therefore, we will test our argument within a context with only limited experience with direct votes i.e. Belgium. Participatory democrats would argue that especially repeated involvement has an educative effect. Yet the participatory democracy framework has also been used to theorize about cases in which involvement is scarcer. This study aims to test whether educative effects can be found using a "one shot" direct democratic process. We expect outcome favorability to be the main driver of change in political support. Given the polarizing nature of a direct vote, we could wonder whether this favorability mechanism also applies to cases with more frequent use of direct democratic processes. Instrumental voting is likely to be triggered there as well. Hence, in these contexts it is also important to gain insight into the potential influence of outcome favorability. Yet this is beyond the scope of this article that focuses on a single direct democratic process in a case with limited experience with this type of decision-making. In particular, we expect:

H3a: Voting for the winning outcome in a referendum increases political support compared to voting for the losing outcome.

To be sure the perceived fairness of or influence in the decision-making process is not driving changes in political support, we also test two alternative hypotheses.

H3b: The perceived fairness of the decision-making process explains the increase in political support following the referendum.

H3c: The perceived influence in the decision-making process explains the increase in political support following the referendum. 


\section{The direct democratic process under study}

Citizen involvement in political decision-making processes can take place at different levels of governance. The local level of government is ideally suited to participate effectively in government, as it offers an ideal context to develop the necessary qualities. It enables citizens to experience and practice to influence decision-making on issues that are generally closely related to their daily lives. The data for this study was gathered in the scope of a referendum on traffic circulation in the medium sized city Mechelen in the Dutch speaking part of Belgium in the spring of 2015. Local policymakers aimed to improve the quality of life in one of its central neighborhoods called 'Nekkerspoel', as they assume that the city's population will substantively increase in the coming decades. A major issue in this context was traffic circulation in the neighborhood, as many car drivers from the outskirts of the city passed through the neighborhood in order to reach the city center. Therefore, the policymakers aimed to reduce this traffic, steaming from car drives whose destination is not located in the neighborhood.

In consultation with its inhabitants the city's administration drafted a new circulation plan that aimed to drastically reduce east-west traffic within the neighborhood. However, soon after the plans were presented to the public, fierce resistance arose among some of the inhabitants, mainly because they feared that the new circulation plan would reduce their own mobility within the neighborhood. Therefore, the city's administration agreed that a group of citizens who opposed the circulation plan could draft an alternative scenario which would fulfill some basic conditions and that a referendum would be held in which all inhabitants of the neighborhood above the age of 16 could choose between the circulation plan that was drafted initially (scenario A) and the alternative circulation 
plan (scenario B) which turned out to be more similar to the status quo. ${ }^{2}$ Despite the consultative nature of Belgian direct democratic instruments, the policymakers promised beforehand that the result of the direct vote would be respected and implemented shortly afterwards. Hence, winning in this context means that the outcome one preferred in the referendum was also implemented. Different results might emerge if the outcome of the referendum would not be implemented and 'winners' would only win the referendum and not the policy decision (Ulbig 2008).

The referendum was held on the $26^{\text {th }}$ of April in 2015 and about 2,000 inhabitants of 7,700 eligible inhabitants casted a ballot (about 26 percent). With 63 percent of the voters choosing the alternative, less interfering circulation plan (scenario B), the vote was clear. The result was announced on the same evening and the new circulation plan was implemented in the weeks following the referendum. The referendum attracted a lot of attention within the neighborhood. In the weeks before the referendum, only about 7 percent of the inhabitants that participated in our survey indicated that they had not yet heard about it. Also, about 57 percent of the inhabitants assumed that a change in the circulation plan would have a strong effect on their daily mobility. Hence, it is safe to assume the referendum was a salient topic for the citizens living in this neighborhood and it is likely to affect their political opinions.

\section{Research Design}

\section{Data}

In order to gain insight into how and why the use of a direct democratic process affects citizens' political support, we developed a design that allows a stronger causal test than cross-sectional studies

\footnotetext{
${ }^{2}$ Following Altman (2014), we can distinguish between different types of direct democratic instruments based on who took the initiative, whether it is binding and whether it is proactive or reactive. While inhabitants did not formally gather signatures to demand for a referendum, it is clear the direct democratic process was the result of popular demand. The process can be best characterized as a bottom-up rather than a top-down process as it was organized as a reaction to protest from citizens against a proposed decision and citizens were included in drafting the answering possibilities.
} 
and allows shedding light on the causal mechanism. We rely on a unique panel dataset containing public opinion data before and after the referendum was held. By tracking individuals over time, we are able to gain insight into the trends in citizens' political support and the factors that can explain these trends. In particular, data on civic attitudes and political orientations was collected using postal surveys in the month before the referendum (Wave 1) and in the three months following the referendum (Wave 2) in the neighborhood in which citizens had the right to participate in the referendum (i.e. 'treatment group'). While such a dynamic design has been used in previous studies on referendums (e.g. de Vreese 2004, De Vries 2009, Sack 2017), we complement this approach with data that was gathered in a 'comparison group'. This means that for both waves, the same questions were asked in a postal survey that was conducted in a comparable neighborhood of the same city in which no referendum was held ${ }^{3}$. This second sample allows us to take changes in citizens' support into account that are not related to the referendum. In both neighborhoods respondents were selected based on a random sample that was drawn from the city's official register of residents (i.e. 1,800 citizens in each neighborhood).

In the first wave 1,360 completed surveys were received (620 from the treatment group and 720 surveys from the comparison group) resulting in a response rate of about 38 percent. Those respondents were re-contacted in the second wave and we obtained filled in questionnaires from 1,119 respondents (512 from the treatment group and 607 from the comparison) resulting in a response rate of 31 percent for both waves. We compared the respondents' main socio-demographic data in all waves and excluded respondents for which sex and age did not match between the waves or did not correspond to the information from the register of residents, leaving us with consistent

\footnotetext{
${ }^{3}$ All respondents were originally contacted by post. They also had the opportunity to complete the questionnaire online using their personalized login data that was distributed together with the postal survey.
} 
data from 1,049 respondents (out of which 483 stem from the treatment group and 566 from the comparison group). The sample offers a good representation of the population in both neighborhoods in terms of sex with a slight overrepresentation of older respondents ${ }^{4}$. As is common in election studies, voters are overrepresented as approximately half the sample in the 'treated' neighborhood indicated to have voted in the referendum ${ }^{5}$. Respondents in the treatment group did provide a good representation of the neighborhood in terms of their vote choice. The referendum resulted in 63 percent of the voters in the neighborhood voting for scenario B. This is within the 95 percent confidence interval of 52 to 65 percent calculated based on our sample.

The design of this study is diagrammed in Table 1. It is based on a 'treatment' group and an 'untreated comparison' group with both pre- and posttest data gathered in the same units (Shadish et al. 2002). It is particularly well-suited to study causality because of the longitudinal nature of the data as well as the comparison group which allows to take contextual changes into account. The dynamic design with comparison group offers a unique novel research design in the field of direct democracy research. It allows studying the short-term effects of the use of one direct democratic process at the local level in depth.

\section{Table 1 Two Group-Pretest-Posttest-Design}

\footnotetext{
${ }^{4}$ Based on the information from the city's register of residents, we compared those 1,049 respondents that answered twice with the respondents that answered only once or not at all. Results show no statistically significant difference on the 5 percent level in terms of sex. With an average age of 52, the group of consistent respondents is significantly older than the group of non-respondents and respondents that participated in only one wave. The average age in this group is 45 . In the entire sample that we drew, the average age is 47.

${ }^{5}$ Unfortunately, no voter validation data is available in Belgium. The fact that we can predict the outcome of the referendum well seems to indicate that rather than biased self-reports, the overrepresentation of voters in our sample is driven by a higher non-response among non-voters.
} 


\begin{tabular}{cccc}
\hline & $\begin{array}{c}\text { Wave 1 } \\
\text { 27 March 2015 - } \\
\text { 25 April 2015 }\end{array}$ & $\begin{array}{c}\text { Referendum } \\
\text { 26 April 2015 }\end{array}$ & $\begin{array}{c}\text { Wave 2 } \\
\text { May 1 } \text { 1 }^{\text {st } 2015 ~-~} \\
\text { 31 July 2015 }\end{array}$ \\
\cline { 2 - 4 } & Pretest & $\mathrm{X}$ & Posttest \\
\hline Treatment Group & $\mathrm{O}_{1}$ & $\mathrm{O}_{2}$ \\
\hline Comparison Group & $\mathrm{O}_{3}$ & $\mathrm{O}_{4}$ \\
\hline
\end{tabular}

Critical to this design is that the treatment and comparison group are as similar as possible (Remler and van Ryzin 2010). The comparison group was carefully chosen within the same municipality (i.e. Mechelen), thereby inhabitants in both neighborhoods have the same policymakers. Further, the choice of comparison neighborhood in the city was based on its average declared income in 2008 which is highly similar to the average declared income in the 'treated' neighborhood". The two neighborhoods are also highly similar in terms of ethnic diversity. We further checked whether the distribution of relevant socio-demographics and political attitudes differs among the respondents from the two neighborhoods and found no differences between the two neighborhoods on possible confounders such as sex, age, level of education, political interest and generalized trust (Table 2).

Next to the comparability of both neighborhoods, it is important that direct democratic processes are as likely in both neighborhoods to avoid endogeneity. Based on interviews with the policymakers and civil servants, it was clear that there are no systematic differences in the likelihood of the use of direct democratic processes within the different neighborhoods. Finally, to act as a comparison group, it is important that the group of citizens that is 'treated' by a referendum is compared to an 'untreated' group. Due to the choice for two neighborhoods in the same municipality, it is possible that the use of the direct democratic process in one neighborhood might influence the opinions of inhabitants in the other neighborhood. Hence, the choice for two

\footnotetext{
${ }^{6}$ We used fiscal data from the Belgian Federal Government from 2008 because it was the most recent data available for statistical sectors at the time of sampling.
} 
neighborhoods in the same municipality maximizes comparability and lowers endogeneity problems, also has a downside.

While we cannot fully avoid that inhabitants in the comparison neighborhood were influenced by the use of a direct democratic process in a different neighborhood, the survey data show strong differences among both neighborhoods in knowledge and salience of the referendum and the issue which indicates the second sample can offer a good comparison group. For instance, the first wave data reveal that unlike the treatment group, a large group of inhabitants in the comparison group was not aware that a referendum would take place (38 percent) or only recently heard about it (14 percent). Further, the second wave data reveals that the overall majority of the respondents in the comparison group (i.e. 91 percent) believes that a change in the traffic circulation in the neighborhood of the treatment group would affect their daily mobility weakly or not at all. In sum, the second sample is not a strict control group as one can create in an experimental setting, yet it does offer a good comparison group outside the lab, which allows to not only investigate changes in citizens' support over time but also to investigate to what extent these changes are unique to the occurrence of a referendum in the neighborhood.

Table 2 Comparison of socio-demographic and attitudinal characteristics respondents

\begin{tabular}{lllll}
\hline & & $\begin{array}{l}\text { Treatment } \\
\text { group }\end{array}$ & $\begin{array}{l}\text { Comparison } \\
\text { group }\end{array}$ & Difference \\
\hline Percentage female respondents & 52.59 & 54.42 & -1.83 \\
\hline Average age & 50.93 & 52.68 & -1.75 \\
\hline $\begin{array}{l}\text { Percentage respondents with no or primary } \\
\text { education }\end{array}$ & 23.00 & 21.44 & 1.56 \\
\hline $\begin{array}{l}\text { Percentage respondents with secondary } \\
\text { education }\end{array}$ & 31.86 & 33.15 & -1.29 \\
\hline $\begin{array}{l}\text { Percentage respondents with tertiary } \\
\text { education }\end{array}$ & 45.15 & 45.41 & -0.26 \\
\hline $\begin{array}{l}\text { Average level of political } \\
\text { (measured on a 10 point scale) }\end{array}$ & interest & 5.47 & 5.33 & 0.14 \\
\hline \begin{tabular}{l} 
Average level of generalized trust \\
\hline
\end{tabular} & 5.58 & 5.59 & -0.01 \\
\hline
\end{tabular}




\begin{abstract}
(measured on a 10 point scale)

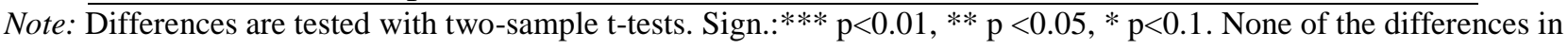
the sample were statistically significant.
\end{abstract}

\title{
Measurement
}

Given that the referendum was at the local level, we investigate citizens' local political support using three indicators. First, we measured satisfaction with local policy using the question: "To what extent are you satisfied with the policy choices of the mayor and councilors of your city?" Respondents could answer on a 5-point scale ranging from 1 "very dissatisfied" to 5 "very satisfied". For trust in local authorities, we used the questions: "Can you indicate on a scale from 0 to 10, how much trust do you have in city's local council?" and "Can you indicate on a scale from 0 to 10, how much trust do you have in city's mayor and the councilors?". As the answers to both questions were highly correlated (0.94 in the first wave and 0.95 in the second wave), we combined them in an index ranging from 0 to 10 with a mean of 5.27 in the first wave and 5.53 in the second wave (corresponding standard deviations are 2.42 in wave one and 2.28 in wave two). Finally, evaluations of democratic performance were assessed using the question "How democratic do you think your city is currently governed?" Respondents could answer on an 11-point scale ranging from 0 "not at all democratic" to 10 "completely democratic".

To gain insight into the causal mechanism (outcome favorability, perceived fairness, perceived influence), we asked respondents in the post-wave whether they voted, and on which scenario they voted and recoded them as "winners" or "losers" of the outcome of the referendum. In addition, we asked about respondents' perceptions of the decision-making process. We rely on two questions that were only asked in the post-wave of the survey: "How fair do you think that the referendum proceeded?" and "how much influence did you have on the decision about the traffic circulation in 
Nekkerspoel?". Respondents indicated their answer on 8-point scales that ranged from 0 "not fair at all" to 7 "very fair" for the first question and from 0 "not influence at all" to 7 "very strong influence" for the second question. Finally, we also asked their opinion about the quality of the decision outcome to gain additional insights into the reasons underlying changes in citizens' support: “How good do you think the decision is that has been taken?" from 0 "not good at all" to 7 "very good"

\section{Method}

In a first step, we look at the changes that occurred in the treatment group between both waves. In a second step, we take the comparison group into account by means of a difference-in-differences strategy to identify the effects of the referendum (Remler and van Ryzin 2010). Given that traffic circulation was a highly salient subject in the treatment group, we expect that citizens' political support changed during the observation period in the treated neighborhood. The difference-indifferences strategy departs from the assumption that if the referendum would not have been held, the average change in citizens' support in the treatment group would have been the same as in the comparison group ("parallel trends assumption"). Therefore, we compare the pre- and postdifference in support between the two neighborhoods and investigate whether the rate of change is different.

During the entire period of observation, we followed the two neighborhoods closely to be sure no intervening events happened between the pre- and the posttest in one neighborhood, except for the referendum, which could affect inhabitants' political attitudes. This condition was met. Therefore, the assumption that potential changes in political support in the treatment group between the two points of measurement can mainly be attributed to the referendum receives support. The difference-

\footnotetext{
${ }^{7}$ Summary statistics on all variables used in the analysis can be found in Appendix (Table A1).
} 
in-differences strategy allows to control for unobservable and time-invariant characteristics of the respondents as we investigate changes within individuals and try to control for contextual effects as good as possible. In a third and final step, we conduct a first difference regression analysis to gain more insight into the causal mechanism underlying the changes in citizens' support. $^{8}$

\section{Results}

The pre- and post-measurements in the treatment group reveal that changes occurred in citizens' political support: satisfaction with local policy and trust in local political authorities seemed to increase after the referendum, while evaluations of local democratic performance seemed to decrease. However, only the increase in trust in local political authorities is significant (see "TG" column in Table 3). The question arises whether this change occurred as a result of the referendum or whether it is part of a general trend that would have also occurred without the referendum. In effect, political support measurements also changed over time in the comparison group in which no referendum was held. In particular, democratic performance evaluations decreased significantly (see “CG” column in Table 3). ${ }^{9}$

In order to answer this question more systematically, we conducted a difference-in-differences analysis in which we study changes in political support in the treatment group while accounting for the changes in political support in the comparison group. The difference-in-differences analysis

\footnotetext{
${ }^{8}$ Data and replication code for the analyses and figures is available at the journal's Dataverse page (see https://dataverse.harvard.edu/dataset.xhtml?persistentId=doi:10.7910/DVN/WKQTNZ).

9 The careful monitoring of both neighborhoods and interviews with policymakers and civil society organizations did not point at another major political event in the city during this timeframe that could help us explain the differential trends in the comparison group. While explaining the reason for the trend in the comparison group is beyond the scope of the study, we should note that the possibility of change in the comparison group is exactly why we included a comparison group in our design. This second sample allows us to take changes over time into account that are unrelated to the referendum. Given that the likelihood of a referendum is as large in both neighborhoods and our survey reveals the policy change resulting from the referendum was not seen as influential to the inhabitants in the comparison group, it is safe to assume the changes in citizens' support in the comparison group are unrelated to the referendum in another neighborhood of the city.
} 
shows that satisfaction with local policy remained stable in both neighborhoods (see "Change" in Table 3). Trust in local political authorities was significantly lower in the treatment group before the referendum but this significant difference could no longer be observed after the referendum given the different rates of change in support in the treatment and comparison group. The strict statistical test of this difference-in-differences does not reach standard levels of significance. Democratic performance evaluations remained stable in the treatment group but significantly declined in the comparison group. This difference-in-differences test is statistically significant. In sum, these findings provide only partial support for the first hypothesis that theorized the referendum would lead to an aggregate increase in citizens' political support. In the following step we try to explain these aggregate changes by shedding light on the causal mechanism.

Table 3 Comparison of difference between two pre-post differences in citizens' support

\begin{tabular}{|c|c|c|c|c|}
\hline & & TG & $\mathbf{C G}$ & $\begin{array}{l}\text { Difference } \\
\text { TG-CG }\end{array}$ \\
\hline \multirow{3}{*}{$\begin{array}{l}\text { Satisfaction with local } \\
\text { policy }(1-5)\end{array}$} & Before the referendum & 3.34 & 3.62 & $-0.28 * * *$ \\
\hline & After the referendum & 3.39 & 3.54 & $-0.15 * * *$ \\
\hline & Change & 0.05 & -0.08 & 0.13 \\
\hline \multirow{3}{*}{$\begin{array}{l}\text { Trust in local authorities } \\
(0-10)\end{array}$} & Before the referendum & 5.07 & 5.44 & $-0.37 * *$ \\
\hline & After the referendum & 5.43 & 5.63 & 0.20 \\
\hline & Change & $0.36 * *$ & 0.19 & 0.17 \\
\hline \multirow{3}{*}{$\begin{array}{l}\text { Democratic performance } \\
\text { evaluations }(0-10)\end{array}$} & Before the referendum & 6.20 & 6.71 & $-0.51 * * *$ \\
\hline & After the referendum & 6.14 & 6.20 & -0.06 \\
\hline & Change & -0.06 & $-0.51 * * *$ & $0.45 * *$ \\
\hline
\end{tabular}

Note: $\mathrm{N}=1,049 . \mathrm{TG}=$ Treatment group (i.e. neighborhood with referendum). $\mathrm{CG}=$ Comparison group (i.e. neighborhood without a referendum). Sign.: *** $\mathrm{p}<0.01, * * \mathrm{p}<0.05, * \mathrm{p}<0.1$.

First, we investigate - in line with the second hypothesis - whether changes in political support differ between voters and non-voters. We do not look at absolute levels as voters and non-voters 
might have different levels of political support before the referendum, but we look at the changes in political support during the observation period. Table 4 shows that the trends in citizens' support are strongly influenced by changes in voters' support. Voters' satisfaction with local policy increased with 0.13 points which is significantly different from the decrease in satisfaction among non-voters in the treatment group and the respondents of the comparison group. Voters' trust in local political authorities increased with 0.55 points, which is significantly more than the modest increases among non-voters and the comparison group. Finally, voters' local democratic performance evaluations also increased, while there was a modest decrease in these evaluations among non-voters and the comparison group. The differences between the changes in support of non-voters and the respondents in the comparison group are all not significant. These analyses suggest that the use of an ad hoc referendum to make a political decision can boost citizens' political support but the opportunity to participate is not sufficient. It is striking that there is no significant difference in the rate of change in political support between inhabitants of the treatment group that choose not to participate in the referendum and the inhabitants of the comparison group that did not have the opportunity to participate. In sum, in line with our expectations and the second hypothesis, voting in the referendum increased political support.

Table 4 Gaining insight into change in citizens' political support

\begin{tabular}{llll}
\hline Satisfaction local policy (1-5) & $0.13^{\mathrm{a}}$ & $-0.02^{\mathrm{b}}$ & $-0.07^{\mathrm{b}}$ \\
\hline Trust in local political authorities (0-10) & $0.55^{\mathrm{c}}$ & $0.11^{\mathrm{d}}$ & $0.18^{\mathrm{d}}$ \\
\hline Democratic performance evaluations (0-10) & $0.23^{\mathrm{e}}$ & $-0.38^{\mathrm{f}}$ & $-0.51^{\mathrm{f}}$ \\
\hline
\end{tabular}

Note: $\mathrm{N}=1,049$. Differences are tested with three ANOVA tests that both revealed significant results at the 0.05 level. Sheffe posthoc tests are visualized by letters ( $\mathrm{a}$ and $\mathrm{b}$ for Satisfaction with policy posthoc tests. $\mathrm{C}$ and $\mathrm{d}$ for Trust posthoc tests. E and F for Democratic performance posthoc tests). Coefficients with the different letters differ significantly at the 0.05 level. 
In a next step, we try to gain more insight into why voters' political support increased over time. We test the third hypothesis that changes in voters' support are driven by outcome favorability. In these analyses we also do not focus on absolute levels but on change in citizens' support over time. In particular, we use first difference regressions where the dependent variables are the change in satisfaction with local policy, trust in local political authorities and democratic performance evaluations that occurred between the measurement before the referendum and the measurement after the referendum. Positive values on these variables indicate that support rose, whereas negative values point to a decline. As a result, this design allows us to study whether support among voters increased after the referendum compared to non-voters and which factors can account for this. As we know that the respondents of the survey are significantly older than the non-respondents, we included respondent's age as a control variable.

In Model I (see Figure 1 and also Table A2 in Appendix) we distinguish between those who voted for the option receiving the majority of the votes (i.e. the 'winners' of the referendum) and those who voted for the option receiving the minority of the votes (i.e. the 'losers' of the referendum) and we compare both groups to those abstaining from voting (i.e. the non-voters). As Figure 1 shows, the rise in all indicators of political support is significantly higher for the 'winners' compared to the non-voters. The support of the 'losers' did not change more or less than the support of the nonvoters. This implies, in line with hypothesis $3 \mathrm{a}$, that the positive effect of participation is driven by changes among the winners of the referendum. Positive effects on citizens' support do not stem from the opportunity to get involved but rather from whether one belongs to the winners of the decision. Hence, the "support gap" documented within election studies (e.g. Anderson et al. 2007) can also been found in this direct democratic process. While the effect sizes are rather modest it has to be kept in mind that we are not investigating absolute levels but changes of political support as 
dependent variables. We can conclude that outcome favorability plays a critical role in explaining the aggregate positive effect of participation in this direct democratic process on citizens' political support.

Fig. 1 The effect of winning on the change in citizens' support

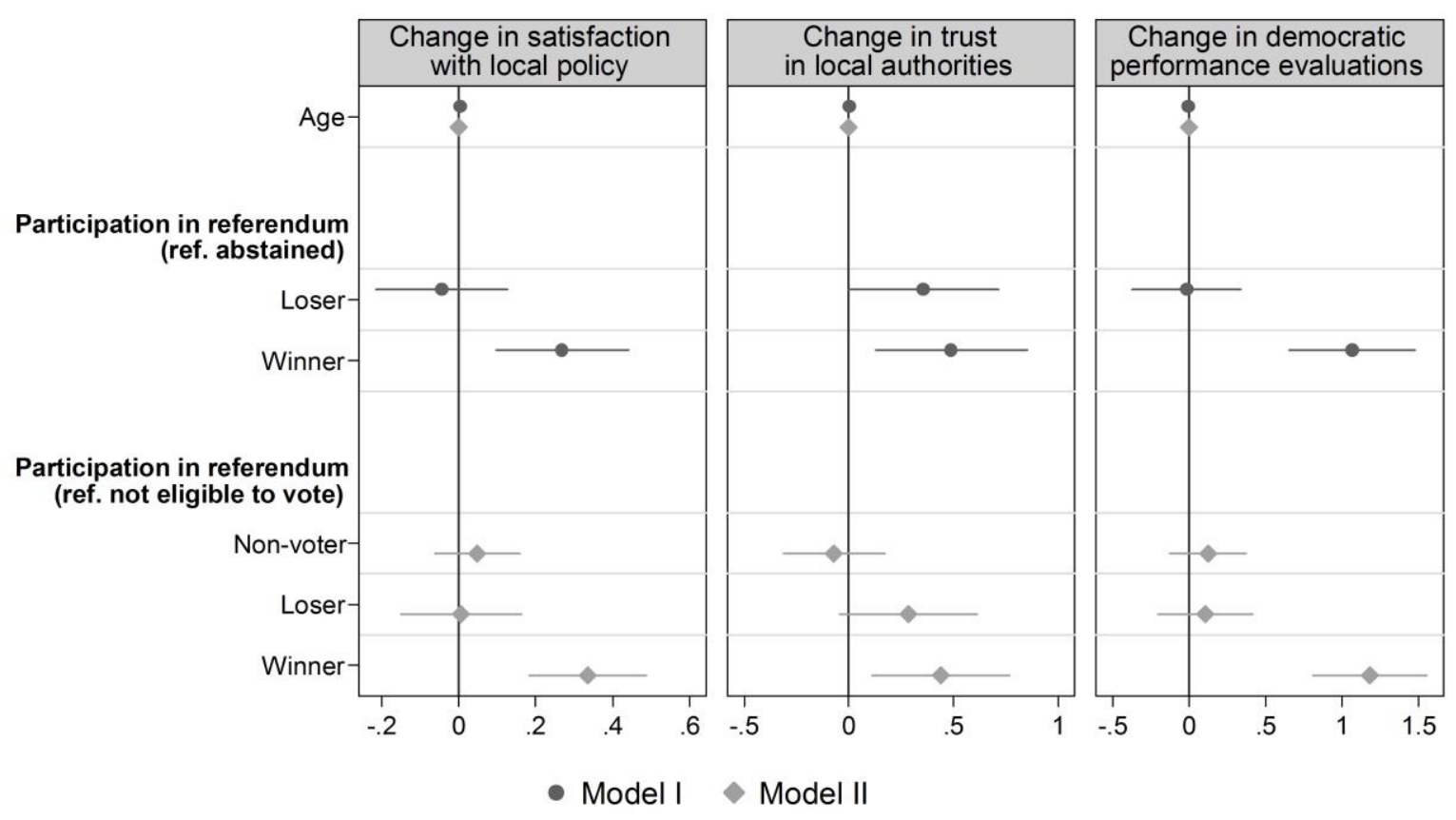

Note: Regression coefficients are illustrated together with confidence intervals (lines). Independent variables are labelled on the y-axis. Coefficients are based on models that are first difference regressions where the dependent variable is the change in satisfaction with local policy, change in trust in local authorities, change in democratic performance evaluations from before to after the referendum (see Table A2, Appendix).

In Model I we studied the change in citizens' political support in the neighborhood with the referendum. We did not account for the general trend in these attitudes documented in Table 3, such as the decline in democratic performance evaluations in the comparison neighborhood without referendum. In order to take these general trends that do not relate to the referendum into account, we contrast the changes in winners' support not only to the losers and the non-voters but also to the 
respondents who did not have the opportunity to vote in this referendum (i.e. comparison group as reference category). As Model II shows, the changes in support of losers and non-voters in the treatment group do not differ from the changes in the comparison group. We can conclude that the "support gap" does not arise because losers and non-voters became particularly dissatisfied and distrusting as an analysis on solely the 'treated' neighborhood with the referendum might suggest. In contrast, this "support gap" results from the rise in winners' support for the political system that granted their wishes, while losers retained their support despite their losses.

\section{Testing alternative mechanisms}

Finally, we test two alternative causal mechanisms that are prominent in previous studies. In particular, in an additional analysis we investigate the effect of perceived fairness and perceived influence in the political decision-making process on changes in citizens' political support. The results of these analyses are presented in Figure 2 (see also Table A3 in Appendix) ${ }^{10}$. In Model III we show the effect of voting compared to abstaining on changes in political support controlled for age: Trust in local political authorities as well as democratic performance evaluations increase more strongly among voters, while no general effect of voting can be documented for satisfaction with local policy. More importantly, in Model IV perceived fairness of the decision-making process and the perception of influence over the outcome of the decision-making process are added to the model to try to explain these increases in political support. We also include the perceived quality of the decision as an additional robustness check. The results in Figure 2 show that these variables are unable to explain the change in political support. The variables are insignificant and the effect of having participated remains significant for both change in trust in local authorities and change in

\footnotetext{
${ }^{10}$ Introducing these variables singlehandedly into the analysis does not change the main conclusion of this additional analysis: The effect of participation in the referendum on changes in trust on local authorities and democratic performance evaluations is not mediated by procedural fairness perceptions or perceptions of influence on the decisionmaking process.
} 
democratic performance evaluations which contradicts the idea that participation is mediated by perceived fairness or influence over the decision. In sum, while outcome favorability can explain changes in citizens' political support following the referendum, perceptions of the decision-making process fail to explain these changes.

Fig. 2 The effect of voting and outcome favorability on changes in citizens' political support

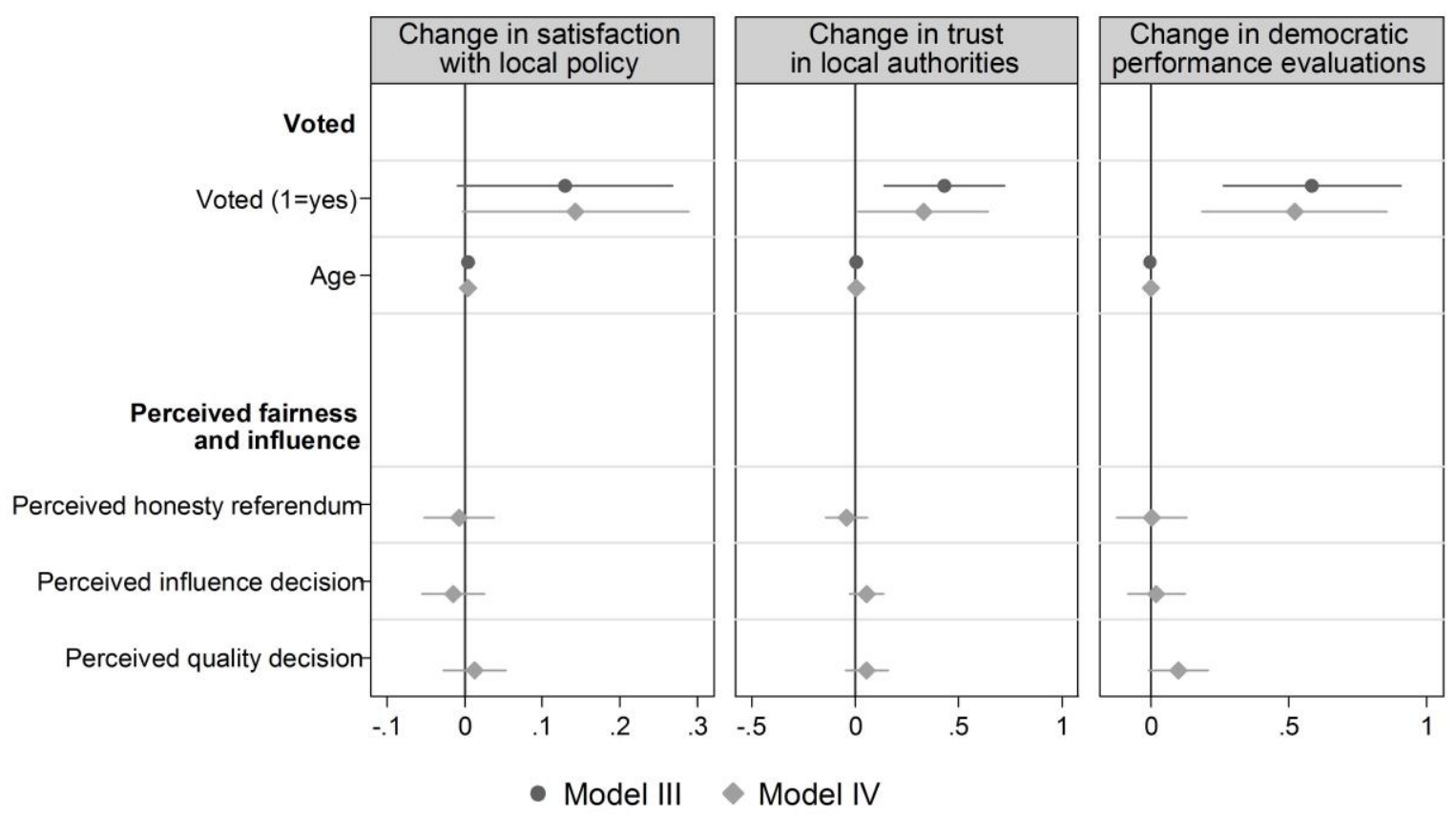

Note: Regression coefficients are illustrated together with confidence intervals (lines). Independent variables are labelled on the y-axis. Coefficients are based on models that are first difference regressions where the dependent variable is the change satisfaction with local policy, change in trust in local authorities, change in democratic performance evaluations from before to after the referendum (see Table A3, Appendix).

Moreover, further analyses reveal that the perceptions toward the decision-making process and the quality of the outcome of this process are not independent of outcome favorability. Despite their participation in the decision-making process, voters of the losing outcome perceive the decisionmaking process as significantly less fair and perceive they had less influence over the decision than 
decision winners (Table 5). In sum, winning proves to be critical for citizens' perceptions toward the decision-making process and affects their evaluation of the functioning of the democratic process and its institutions. This is in line with results from election studies that show that winners of elections hold more favorable views toward democracy (Shane et al. 2011).

\section{Table 5: Winners average fairness and influence perceptions}

\begin{tabular}{llll}
\hline Change in: & Winners & Non-Winners & Difference \\
\hline Perceived fairness referendum & 5.18 & 4.30 & $0.88^{* * *}$ \\
\hline Perceived influence decision & 4.02 & 2.62 & $1.40^{* * *}$ \\
\hline Perceived quality decision & 4.61 & 3.45 & $1.16^{* * *}$ \\
Note: $\mathrm{N}=1,049$. Average fairness and influence perceptions of winners are compared to those of non-winners (i.e. losers, \\
non-voters and those not eligible to vote) using 3 t-tests. Sign.: $* * * \mathrm{p}<0.01, * * \mathrm{p}<0.05, * \mathrm{p}<0.1$.
\end{tabular}

\section{Conclusion}

In the academic and public debate, more extensive citizen involvement in political decision-making processes is repeatedly presented as a potential solution for democratic dissatisfaction. Recently, Shomer et al. (2016), for instance, show that more extensive citizen involvement in the candidate selection procedures within political parties increases political support. The use of direct democratic procedures are an increasingly popularity way to involve citizens (Altman 2014; Scarrow 2001). Despite the strong theoretical claims on its beneficial effects on political support, only few empirical studies investigated these claims and insight into how and why direct democratic instruments influence political support is almost completely absent. Moreover, recently a number of authors have voiced serious doubts about the beneficial effects of these instruments (e.g. Seabrook et al 2015).

The overall majority of studies on the influence of the use of direct democratic instruments on political support draw on participatory democracy and procedural fairness theory. We question the applicability of the participatory democracy framework to cases in which direct democratic 
processes are not a standard feature of the political decision-making process as participatory democracy theorists envision a completely different political system in which opportunities to participate are abundant. We argue that to understand the short-term effects of the use of a direct democratic instrument on political support, outcome favorability is critical. Outcome favorability will drive changes in political support following the use of a direct democratic process, rather than the perceived fairness of the decision-making process or the perceived influence over the decision outcome. To test this argument, we developed an original research design in which citizens were questioned before and after a referendum took place in a case with limited experience with direct democratic processes. To account for contextual changes in citizens' political support that are unrelated to the referendum, the results of this sample were compared to a sample of a comparable neighborhood without a referendum.

The results show that the referendum led to a significant increase in political support, but only among voters. Neither the perceived fairness of the decision-making process nor the perceived influence over the outcome mediates this positive effect of voting. In line with our expectation, the driving force behind this increase is having voted for the outcome that received the majority of the votes. In a direct democratic process, winners are by definition the majority which leads to a short-term increase in political support on the aggregate level. We also showed - despite the polarizing nature of a direct democratic vote and despite the contested nature of the issue - that losers' levels of political support remained stable. This could be a reason for optimism about the potential of using direct democratic processes to decide on contested issues. This seems especially important because representative decision-making processes on similar issues could lead to losses among losers. A recent study in Sweden showed that following a decision on a contested issue using a representative decision-making process, decision losers became less supporting of the political system and this 
negative effect proved to be remarkably stable over time (Esaiasson et al. in press). A recent study that explicitly compares direct and representative processes further corroborates this conclusion (Towfigh et al. 2016).

Recently, democratic theorists have stressed the need to go beyond thinking in terms of 'models' of democratic decision-making processes toward a problem-based approach that looks into which particular decision-making process matches the problem at hand (Warren 2017). In this context, it becomes even more important to gain a good understanding of how and why different decisionmaking processes affect political support. This study reveals that direct democratic instruments might be better than a purely representative process to decide on a contested issue. We could speculate that outcome favorability might even be less or not at play if more consensus-based procedures would be used. More deliberative forms of involvement might increase political support among winners and losers given that these forms are less polarizing in nature and enhance preference transformation and consensus seeking. A direct democratic process is indeed not well-suited to stimulate preference transformation. For example, when a vote is announced in a deliberative process, the deliberative quality of the debate has been found to go down and people stick to their opinions (Felicetti et al. 2016; Ercan and Gagnon 2014, p. 6). Yet we could also question whether the expectation of an increase in support among decision losers might be too high of an expectation.

We could speculate that when direct democratic instruments are extensively used different effects could be found compared to this one-shot use under study. However, also in this case outcome favorability could be important in shaping people's opinions towards these decision-making processes and the political system more generally because of its polarizing nature. It is also important to note that the availability of these instruments could have a different impact than its use. While a direct vote could be a good procedure to make a contested decision while keeping losers on 
board, the availability of these instruments might strengthen political support in the long run among all citizens, as this availability signals they could have a say in the decision making process.

While this study offers important insights into the effect of direct democratic decision-making on political support, it also has several limitations. First, as is common in all survey research, the findings could be influenced by non-response bias. In particular, non-voters were more likely not to participate in the survey. While the survey gives a representative picture of the winners and losers of the vote, despite our efforts non-voters were underrepresented in the survey. Second, we choose to study one case in depth, which inherently limits the generalizability. While this case can be seen as a typical case of a direct democratic process in a system that does not use these instruments frequently, more research of other cases is needed to investigate its generalizability to other cases and countries. The design we developed offers advantages for future studies as it allows investigating the driving forces behind public opinion changes following a direct democratic process. To date, the majority of the empirical evidence is focused on long-term effects and cases in which direct democratic instruments are frequently used such as some states in the US or Swiss cantons. We should be careful to generalize from those cases. The long-term effects resulting from the use of direct democratic processes as a standard feature of the political decision-making process could be different from the short-term effect of the use of a direct democratic process. Repeated winning and losing could teach citizens that next time they could win, which could increase their support for the democratic process. In contrast, extensive participation opportunities could also lead to repeated losses, which might lead to declining support whereas one occasional loss might not affect losers' support. Too frequent calls for participation might also lead to fatigue (Kern and Hooghe in press). In sum, it is critical to get information on a variety of cases to also gain insight into potential contextual factors. We believe this in depth study of a case in which direct democratic 
processes are scarce is an important step in this direction. Yet its generalizability is inherently limited. Also the nature of the issue under study - a local infrastructure project - might affect the findings. Direct democratic processes that focus on other types of issues (e.g. more identity-based issues such as a ban on veils or mosques) might have different effects on political support. We should also be careful in generalizing these effects of a local referendum to the national level.

Third, in this study we only investigated short-term effects. Noteworthy, before the referendum citizens' political support was lower in the treated neighborhood than in the comparison neighborhood. We could speculate that the heated discussions about the traffic circulation plans lowered support in the treated neighborhood (documented in the pre-test). After the referendum support levels might have returned to its original levels (documented in the post-test). Furthermore, it is possible that the policy which resulted from the referendum (i.e. the new circulation plan) will have a positive effect on political support of both, winners and losers, in the long-run. Therefore, it would be interesting if future studies would be able to extend the panel design even further and add an additional post-wave to study long-term effects.

Fourth, we did not investigate the potential effect of the availability of direct democratic instruments on political support. The referendum was already announced during the pre-test wave. Therefore, only the effect of the use of the referendum can be studied by comparing voters to non-voters and to citizens in another neighborhood that did not have the opportunity to vote. While an increase in support was only documented among decision winners, the mere availability of this instrument might have a positive effect across the citizenry. Therefore, it is important that scholars are clear in their expectations and object of study. We believe that disentangling the difference between availability and use includes a fruitful avenue for research. In sum, there is still an extensive research agenda. We believe this study already offers a number of important insights into how and why direct 
democracy influences citizens' political support by steering our attention to outcome favorability and the nature of the winner-loser support gap using a novel case that is characterized by citizens' limited experience with direct democratic processes.

\section{Ethical approval}

All procedures performed in studies involving human participants were in accordance with the ethical standards of the institutional and national research committee and with the 1964 Helsinki declaration and its later amendments or comparable ethical standards. Informed consent was obtained from all individual participants included in the study.

\section{References}

Altman, D. (2014). Direct Democracy Worldwide. Cambridge: Cambridge University Press.

Anderson, C. J., Blais, A., Bowler, S., Donovan, T., \& Listhaug, O. (2007). Losers' Consent: Elections and Democratic Legitimacy. Oxford: Oxford University Press.

Anderson, C. J., \& LoTempio, A. J. (2002). Winning, Losing and Political Trust in America. British Journal of Political Science 32(2), 335-351.

Arnesen, S. (2017). Legitimacy from Decision-Making Influence and Outcome Favourability: Results from General Population Survey Experiments. Political Studies 65(1S), 146 -161.

Barber, B. R. (2003). Strong Democracy: Participatory Politics for a New Age. Berkeley: University of California Press [original 1984].

Bauer, P. C., \& Fatke, M. (2014). Direct Democracy and Political Trust: Enhancing Trust, Initiating Distrust-or Both? Swiss Political Science Review, 20(1), 49-69.

Blais, A., \& Rubenson, D. (2013). The Source of Turnout Decline: New Values or New Contexts? Comparative Political Studies, 46(1), 95-117.

Bowler, S., \& Donovan, T. (2002). Democracy, Institutions and Attitudes about Citizen Influence on Government. British Journal of Political Science, 32(2), 371-390.

Bryan, F. M. (2003). Real Democracy. The New England Town Meeting and How it Works. Chicago: University of Chicago Press.

Craig, S. C., Martinez, M. D., Gainous, J., \& Kane, J. G. (2006). Winners, Losers, and Election Context: Voter Responses to the 2000 Presidential Election. Political Research Quarterly, 59(4) 579-592.

Dahl, R. (1989). Democracy and its Critics. New Haven: Yale University Press.

Dalton, R. J., \& Welzel, C. (2014). The Civic Culture Transformed: From Allegiant to Assertive Citizens. New York: Cambridge University Press. 
De Cremer, D., \& Tyler, T. (2007). The Effects of Trust and Procedural Justice on Cooperation. Journal of Applied Psychology, 92, 639-649.

De Vries, C. E. (2009). The Impact of EU Referenda on National Electoral Politics: The Dutch Case, West European Politics, 32,1, 142-171.

de Vreese, C. H. (2004). Primed by the Euro: The Impact of a Referendum Campaign on Public Opinion and Evaluations of Government and Political Leaders, Scandinavian Political Studies, 27, 1, 45-64.

della Porta, D. (2013). Can Democracy Be Saved? Participation, Deliberation and Social Movements. Cambridge: Polity Press.

Downs, A. (1957) An Economic Theory of Democracy. New York: Harper \& Row.

Donovan, T. \& Bowler, S. (1998). Direct Democracy and Minority Rights: An Extension. American Journal of Political Science, 42(3), 1020-1024.

Dyck, J. J. (2009). Initiated Distrust: Direct Democracy and Trust in Government. American Politics Research, 37(4), 539-568.

Dyck, J. J., \& Lascher, E. L. (2009). Direct Democracy and Political Efficacy Reconsidered. Political Behavior, 31(3), 401-427.

Easton, D. (1975). A Re-Assessment of the Concept of Political Support. British Journal of Political Science, 5(4), 435-457.

Ercan, S. A., \& Gagnon, J.-P. (2014). The Crisis of Democracy: Which Crisis? Which Democracy? Democratic Theory, 1(2), 1-10.

Esaiasson, P. (2011). Electoral Losers Revisited. How Citizens React to Defeat at the Ballot Box, Electoral Studies, 30, 102-113.

Esaiasson, P., Gilljam, M., \& Persson, M. (2012). Which Decision-Making Arrangements Generate the Strongest Legitimacy Beliefs? Evidence from a Randomised Field Experiment. European Journal of Political Research, 51(6), 785-808.

Esaiasson, P., Persson, M., Gilljam, M., \& Lindholm, T. Reconsidering the Role of Procedures for Decision-Acceptance, British Journal of Political Science. (in press).

Esaiasson, P., Gilljam, M., \& Persson, M. Political Support in the Wake of Policy Controversies. In C. van Ham, J. Thomassen, K. Aarts, \& R. Andeweg (Eds.), Myth and Reality of the Legitimacy Crisis. Explaining trends and Cross-National Differences in Established Democracies. Oxford: Oxford University Press. (in press).

Fehr, E. \& Schmidt, K. M. (1999). A Theory of Fairness, Competition, and Cooperation, The Quarterly Journal of Economics, 114(3), 817-868.

Felicetti, A., Niemeyer, S., \& Curato, N. (2016). Improving deliberative participation: connecting mini-publics to deliberative systems, European Political Science Review, 8(3), 427-448.

Geys, B. (2006). 'Rational' Theories of Voter Turnout: A Review. Political Studies, 4, 16-32.

Gilens, M., Glaser, J., \& Mendelberg, T. (2001). Having a Say: Political Efficacy and Direct Democracy. Paper presented at the Annual Meeting of the American Political Science Association, San Francisco, August 30 - September 2, 2001.

Grimes, M. (2006). Organizing Consent: The Role of Procedural Fairness in Political Trust and Compliance. European Journal of Political Research, 45(2), 285-315. 
Haider-Markel, D. P, Querze, A., \& Lindaman, K. (2007). Lose, Win, or Draw? A Reexamination of Direct Democracy and Minority Rights. Political Research Quarterly, 60(2), 304-314.

Hero, R. E, \& Tolbert, C. J. (2004). Minority Voices and Citizen Attitudes about Government Responsiveness in the American States: Do Social and Institutional Context Matter? British Journal of Political Science, 34(1), 109-121.

Hug, S. (2005). The Political Effects of Referendums: An Analysis of Institutional Innovations in Eastern and Central Europe. Communist and Post-Communist Studies, 38(4), 475- 499.

Ito, Tiffany A., Larsen, J. T., Smith, N. K., \& Cacioppo, J. T. (1998). Negative Information Weights More Heavily on the Brain: The Negativity Bias in Evaluative Categorization. Journal of Personality and Social Psychology, 75(4), 887-900.

Kern, A. (2017). The Effect of Direct Democratic Participation on Citizens' Political Attitudes in Switzerland: The Difference between Availability and Use. Politics and Governance, 5(2), 16-26.

Kern, A., \& Hooghe, M. The Effect of Direct Democracy on the Social Stratification of Political Participation: Inequality in Democratic Fatigue?. Comparative European Politics. (in press).

Leininger, A. (2015). Direct Democracy in Europe: Potentials and Pitfalls, Global Policy, 6(1), $17-27$.

Marien, S. (2011). The Effect of Electoral Outcomes on Political Trust. A Multi-level Analysis of 23 Countries. Electoral Studies, 30(4), 712-726.

Lago, I., \& Martínez, F. Challenge or Consent? Understanding Losers' Consent in Mass Election, Government and Opposition. (in press).

Leemann, L. \& Wasserfallen, F. (2016). The Democratic Effect of Direct Democracy, American Political Science Review, 110(4), 750-762.

Mendelsohn, M., \& Cutler, F. (2000). The Effect of Referendums on Democratic Citizens: Information, Politicization, Efficacy and Tolerance. British Journal of Political Science, 30(4), 669-698.

Miller, A., \& Listhaug, O. (1990). Political Parties and Confidence in Government. A Comparison of Norway, Sweden and the United States. British Journal of Political Science, 20(3), 357386.

Morrell, M. (1999). Citizens' Evaluations of Participatory Democratic Procedures: Normative Theory Meets Empirical Science, Political Research Quarterly, 52(2), 293-322.

Norris, P. (2011). Democratic Deficits. Critical Citizens Revisited. Cambridge: Cambridge University Press.

Oliver, J., Ha, S., \& Callen, Z. (2012). Local Elections and the Politics of Small-Scale Democracy. Princeton: Princeton University Press.

Olken, B. A. (2010). Direct Democracy and Local Public Goods: Evidence from a Field Experiment in Indonesia, American Political Science Review, 104(2), 243-267.

Pateman, C. (1970). Participation and Democratic Theory. Cambridge: Cambridge University Press.

Persson, M., Esaiasson, P., and Gilljam, M. (2013). The Effects of Direct Voting and Deliberation on Legitimacy Beliefs: An Experimental Study of Small Group Decision-Making. European 
Political Science Review, 5(3), 381-399.

Pierce, L., Rogers, T., Snyder, J. A. (2016). Losing Hurts: The Happiness Impact of Partisan Electoral Loss. Journal of Experimental Political Science, 3(1), 44-59.

Polletta, F. (2002). Freedom Is an Endless Meeting: Democracy in American Social Movements. Chicago: University of Chicago Press.

Przeworski, A. (1991). Democracy and the Market: Political and Economic Reforms in Eastern Europe and Latin America. Cambridge: Cambridge University Press.

Qvortrup, M. (2017). Demystifying Direct Democracy, Journal of Democracy, 28(3), 141-152.

Remler, D. K, \& van Ryzin, G. G. (2010). Research Methods in Practice: Strategies for Description and Causation. London: Sage Publications.

Sack, B. C. (2017). Gewinnen, Verlieren und lokale Betroffenheit bei Volksabstimmungen: Auswirkungen auf die Demokratiezufriedenheit im zeitlichen und räumlichen Vergleich, Politische Vierteljahresschrift, 58(1), 75-97.

Scarrow, S. (2001). Direct Democracy and Institutional Change. A Comparative Investigation. Comparative Political Studies, 34(6), 651-665.

Schlozman, D., \& Yohai, I. (2008). How Initiatives Don't Always Make Citizens: Ballot Initiatives in the American States, 1978-2004. Political Behavior, 30(4), 469-489.

Seabrook, N.R., Dyck, J.J., Lascher, E. L. (2015). Do Ballot Initiatives Increase General Political Knowledge? Political Behavior, 37(2), 279-307.

Shadish, W. R, Cook, T. D., \& Campbell, D. T. (2002). Experimental and Quasi-Experimental Designs for Generalized Causal Inference. Boston: Houghton Mifflin.

Shane, S., Blais, A. \& Lago, I. (2011). Winning and Competitiveness as Determinants of Political Support. Social Science Quarterly, 92, 695-709.

Shomer, Y., Put, G. \& Gedalya-Lavy, E. (2016). Intra-Party Politics and Public Opinion: How Candidate Selection Processes Affect Citizens' Satisfaction with Democracy. Political Behavior, 38(3), 509-534.

Skitka, L. \& Wisneski, D. (2012). Justice Theory and Research: A Social Functionalist Perspective. In: Handbook of Psychology. Volume 5: Personality and Social Psychology, eds. H. Tennen \& J. Suls. Hoboken: NJ: John Wiley and Sons.

Smith, D. A., \& Tolbert, C. J. (2004). Educated by Initiative: The Effects of Direct Democracy on Citizens and Political Organizations in the American States. Ann Arbor: University of Michigan Press.

Smith, G. (2009). Democratic Innovations. Designing Institutions for Citizen Participation. Cambridge: Cambridge University Press.

Smith, M. A. (2002). Ballot Initiatives and the Democratic Citizen. The Journal of Politics, 64(3), 892-903.

Soroka, S. N. (2014). Negativity in Democratic Politics Causes and Consequences. Cambridge: Cambridge University Press.

Stadelmann-Steffen, I. \& Vatter, A. (2012). Does Satisfaction with Democracy Really Increase Happiness? Direct Democracy and Individual Satisfaction in Switzerland. Political Behavior, 34(3), 535-559. 
Stolle, D., \& Hooghe, M. (2004). Review Article: Inaccurate, Exceptional, One-Sided or Irrelevant? The Debate about the Alleged Decline of Social Capital and Civic Engagement in Western Societies, British Journal of Political Science, 35, 149-167.

Tolbert, C. J., McNeal, R. S., \& Smith, D. A. (2003). Enhancing Civic Engagement: The Effect of Direct Democracy on Political Participation and Knowledge. State Politics \& Policy Quarterly, 3(1), 23-41.

Towfigh, E. V., Goerg, S. J., Glockner, A., Leifeld, P., Llorente-Saguer, A., Bade, S. \& Kurschilgen, C. (2016). Do direct-democratic procedures lead to higher acceptance than political representation? Experimental survey evidence from Germany. Public Choice, 167, 47-65.

Tyler, T. (2006). Psychological Perspectives on Legitimacy and Legitimation. Annual Review of Sociology 32, 53-78.

Tyler, T. (2011). Why People Cooperate. Princeton: Princeton University Press.

Ulbig, S. G. (2008). Voice is not Enough. The Importance of Influence in Political Trust and Policy Assessments, Public Opinion Quarterly, 72(3), 523-539.

van Biezen, I., Mair, P., \& Poguntke, T. (2012). Going, Going,... Gone? The Decline of Party Membership in Contemporary Europe. European Journal of Political Research, 51(1), 2456.

Vatter, A., \& Danaci, D. (2010). Mehrheitstyrannei durch Volksentscheide? Zum Spannungsverhältnis zwischen direkter Demokratie und Minderheitenschutz. Politische Vierteljahreschrift, 51(2), 122-140.

Verba, S., Schlozman, K. L., \& Brady, H. E. (1995). Voice and Equality. Civic Voluntarism in American Politics. Cambridge: Harvard University Press.

Voigt, S., \& Blume, L. (2015). Does Direct Democracy Make for Better Citizens? A Cautionary Waring Based on Cross-Country Evidence. Constitutional Political Economy, 26(4), 391420.

Wagschal, U. (1997). Direct Democracy and Public Policymaking. Journal of Public Policy, $17(2), 223-245$.

Warren, M. E. (2017). A Problem-Based Approach to Democratic Theory. American Political Science Review, 111(1), 39-53. 


\section{Appendix}

Table A1 Descriptive statistics of variables included in the analysis

\begin{tabular}{|c|c|c|c|c|c|c|}
\hline Variable & Obs. & Mean. & Std. Dev. & Min. & Max & $\begin{array}{l}\text { Missings } \\
\text { in \% }\end{array}$ \\
\hline $\begin{array}{l}\text { Satisfaction with local } \\
\text { policy (W1) }\end{array}$ & 1033 & 3.49 & 0.99 & 1 & 5 & 1.53 \\
\hline $\begin{array}{l}\text { Satisfaction with local } \\
\text { policy (W2) }\end{array}$ & 1048 & 3.47 & 0.88 & 1 & 5 & 0.10 \\
\hline $\begin{array}{l}\text { Change in satisfaction } \\
\text { with local policy (W2- } \\
\text { W1) }\end{array}$ & 1032 & -0.01 & 0.74 & -3 & 4 & 1.62 \\
\hline $\begin{array}{l}\text { Trust in local political } \\
\text { authorities (W1) }\end{array}$ & 1026 & 5.27 & 2.42 & 0 & 10 & 2.19 \\
\hline $\begin{array}{l}\text { Trust in local political } \\
\text { authorities (W2) }\end{array}$ & 1032 & 5.53 & 2.28 & 0 & 10 & 1.62 \\
\hline $\begin{array}{l}\text { Change in trust in local } \\
\text { political authorities } \\
\text { (W2-W1) }\end{array}$ & 1012 & 0.25 & 1.65 & -10 & 7 & 3.53 \\
\hline $\begin{array}{l}\text { Democratic performance } \\
\text { evaluations (W1) }\end{array}$ & 1038 & 6.48 & 2.34 & 0 & 10 & 1.05 \\
\hline $\begin{array}{l}\text { Democratic performance } \\
\text { evaluations (W2) }\end{array}$ & 1037 & 6.17 & 2.08 & 0 & 10 & 1.14 \\
\hline $\begin{array}{l}\text { Change in democratic } \\
\text { performance evaluations }\end{array}$ & 1027 & -0.31 & 1.70 & -5 & 7 & 2.10 \\
\hline \multicolumn{7}{|c|}{ Participation in referendum (among eligible voters) } \\
\hline $\begin{array}{l}\text { Non-voters who were } \\
\text { eligible to vote (ref.)* }\end{array}$ & 469 & 0.51 & 0.50 & 0 & 1 & 2.90 \\
\hline Losers* & 469 & 0.20 & 0.40 & 0 & 1 & 2.90 \\
\hline Winners* & 469 & 0.29 & 0.45 & 0 & 1 & 2.90 \\
\hline \multicolumn{7}{|c|}{ Participation in referendum (among all respondents) } \\
\hline $\begin{array}{l}\text { Respondents who were not } \\
\text { eligible to vote (ref.) }\end{array}$ & 1035 & 0.55 & 0.50 & 0 & 1 & 1.33 \\
\hline $\begin{array}{l}\text { Non-voters who were } \\
\text { eligible to vote }\end{array}$ & 1035 & 0.23 & 0.42 & 0 & 1 & 1.33 \\
\hline Losers & 1035 & 0.09 & 0.29 & 0 & 1 & 1.33 \\
\hline Winners & 1035 & 0.13 & 0.34 & 0 & 1 & 1.33 \\
\hline $\begin{array}{l}\text { Perceived honesty } \\
\text { referendum }\end{array}$ & 956 & 4.41 & 1.79 & 0 & 7 & 8.87 \\
\hline $\begin{array}{l}\text { Perceived influence } \\
\text { decision* }\end{array}$ & 479 & 2.99 & 2.16 & 0 & 7 & 0.83 \\
\hline Perceived quality decision & 949 & 3.60 & 1.86 & 0 & 7 & 9.53 \\
\hline
\end{tabular}

Note: Variables marked with * are only available for the treatment group. The percentage of missing for these variables is calculated based on the 483 respondents from the treatment group. The percentage of missings for the other variables is based on the total number of respondents which is 1,049. There is one respondent whose trust in local political authorities declined with -10 between the first and the second wave. Repeating the analysis without this outlier does not change the results. 
Table A2 The effect of winning on the change in citizens' political support

\begin{tabular}{|c|c|c|c|c|c|c|}
\hline & \multicolumn{2}{|c|}{$\begin{array}{c}\text { Change in } \\
\text { satisfaction with local } \\
\text { policy }\end{array}$} & \multicolumn{2}{|c|}{$\begin{array}{l}\text { Change in trust in } \\
\text { local authorities }\end{array}$} & \multicolumn{2}{|c|}{$\begin{array}{l}\text { Change in } \\
\text { democratic } \\
\text { performance } \\
\text { evaluations }\end{array}$} \\
\hline & I. 1 & II.1 & I. 2 & II. 2 & I. 3 & II. 3 \\
\hline Age & $\begin{array}{c}0.003 \\
(0.002)\end{array}$ & $\begin{array}{c}0.001 \\
(0.001)\end{array}$ & $\begin{array}{c}0.003 \\
(0.005)\end{array}$ & $\begin{array}{l}-0.000 \\
(0.003)\end{array}$ & $\begin{array}{l}-0.004 \\
(0.005)\end{array}$ & $\begin{array}{l}-0.003 \\
(0.003)\end{array}$ \\
\hline $\begin{array}{l}\text { Participation } \\
\text { (ref. not vot }\end{array}$ & & & & & & \\
\hline Loser & $\begin{array}{l}-0.044 \\
(0.087)\end{array}$ & & $\begin{array}{c}0.356 \\
(0.183)\end{array}$ & & $\begin{array}{l}-0.017 \\
(0.180)\end{array}$ & \\
\hline Winner & $\begin{array}{c}0.269 * * \\
(0.087)\end{array}$ & & $\begin{array}{c}0.490 * * \\
(0.183)\end{array}$ & & $\begin{array}{c}1.066^{* * * *} \\
(0.208)\end{array}$ & \\
\hline $\begin{array}{l}\text { Participatior } \\
\text { (ref. compar } \\
\text { eligible to } \mathrm{v}\end{array}$ & & & & & & \\
\hline Non-voters & & $\begin{array}{c}0.049 \\
(0.056)\end{array}$ & & $\begin{array}{l}-0.070 \\
(0.123)\end{array}$ & & $\begin{array}{c}0.122 \\
(0.127)\end{array}$ \\
\hline Loser & & $\begin{array}{c}0.006 \\
(0.080)\end{array}$ & & $\begin{array}{c}0.284 \\
(0.167)\end{array}$ & & $\begin{array}{c}0.106 \\
(0.158)\end{array}$ \\
\hline Winner & & $\begin{array}{c}0.336 * * * \\
(0.077)\end{array}$ & & $\begin{array}{c}0.439 * * \\
(0.167)\end{array}$ & & $\begin{array}{c}1.182 * * * \\
(0.190)\end{array}$ \\
\hline Constant & $\begin{array}{l}-0.185 \\
(0.108)\end{array}$ & $\begin{array}{l}-0.107 \\
(0.072)\end{array}$ & $\begin{array}{c}-0.034 \\
(0.249)\end{array}$ & $\begin{array}{c}0.193 \\
(0.162)\end{array}$ & $\begin{array}{l}-0.200 \\
(0.264)\end{array}$ & $\begin{array}{c}-0.371^{*} \\
(0.163)\end{array}$ \\
\hline $\begin{array}{l}N \\
\text { adj. } R^{2}\end{array}$ & $\begin{array}{c}461 \\
0.033\end{array}$ & $\begin{array}{l}1020 \\
0.019\end{array}$ & $\begin{array}{c}457 \\
0.015\end{array}$ & $\begin{array}{l}1000 \\
0.007\end{array}$ & $\begin{array}{c}461 \\
0.065\end{array}$ & $\begin{array}{l}1016 \\
0.049\end{array}$ \\
\hline
\end{tabular}

Note: Regression coefficients shown with robust standard errors in parentheses. Models are first difference regressions where the dependent variable is the change satisfaction with local policy, change in trust in local authorities, change in democratic performance evaluations from before to after the referendum. Sign.: $* p<0.05, * * p<0.01, * * * p<0.001$. 
Table A3 The effect of voting and outcome favorability on changes in citizens' political support

\begin{tabular}{|c|c|c|c|c|c|c|}
\hline & \multicolumn{2}{|c|}{$\begin{array}{c}\text { Change in } \\
\text { satisfaction with } \\
\text { local policy }\end{array}$} & \multicolumn{2}{|c|}{$\begin{array}{l}\text { Change in trust in } \\
\text { local authorities }\end{array}$} & \multicolumn{2}{|c|}{$\begin{array}{l}\text { Change in } \\
\text { democratic } \\
\text { performance } \\
\text { evaluations }\end{array}$} \\
\hline & III.1 & IV.1 & III.2 & IV.2 & III.3 & IV.3 \\
\hline Age & $\begin{array}{l}0.004 * \\
(0.002)\end{array}$ & $\begin{array}{l}0.004 * \\
(0.002)\end{array}$ & $\begin{array}{c}0.003 \\
(0.005)\end{array}$ & $\begin{array}{c}0.003 \\
(0.005)\end{array}$ & $\begin{array}{l}-0.001 \\
(0.005)\end{array}$ & $\begin{array}{c}0.000 \\
(0.005)\end{array}$ \\
\hline Voted & $\begin{array}{c}0.130 \\
(0.070)\end{array}$ & $\begin{array}{c}0.143 \\
(0.074)\end{array}$ & $\begin{array}{c}0.430 * * \\
(0.148)\end{array}$ & $\begin{array}{l}0.329^{*} \\
(0.159)\end{array}$ & $\begin{array}{c}0.585^{* * *} \\
(0.163)\end{array}$ & $\begin{array}{c}0.521^{* * *} \\
(0.170)\end{array}$ \\
\hline Perceived honesty referendum & & $\begin{array}{l}-0.008 \\
(0.023)\end{array}$ & & $\begin{array}{l}-0.043 \\
(0.051)\end{array}$ & & $\begin{array}{c}0.003 \\
(0.064)\end{array}$ \\
\hline Perceived influence decision & & $\begin{array}{l}-0.015 \\
(0.020)\end{array}$ & & $\begin{array}{c}0.054 \\
(0.042)\end{array}$ & & $\begin{array}{c}0.020 \\
(0.053)\end{array}$ \\
\hline Perceived quality decision & & $\begin{array}{c}0.013 \\
(0.020)\end{array}$ & & $\begin{array}{c}0.055 \\
(0.052)\end{array}$ & & $\begin{array}{c}0.101 \\
(0.054)\end{array}$ \\
\hline Constant & $\begin{array}{c}-0.220^{*} \\
(0.108)\end{array}$ & $\begin{array}{l}-0.182 \\
(0.153)\end{array}$ & $\begin{array}{l}-0.046 \\
(0.246)\end{array}$ & $\begin{array}{l}-0.141 \\
(0.296)\end{array}$ & $\begin{array}{l}-0.347 \\
(0.262)\end{array}$ & $\begin{array}{c}-0.772^{*} \\
(0.340)\end{array}$ \\
\hline $\begin{array}{l} \\
\text { adj. } R^{2}\end{array}$ & $\begin{array}{c}467 \\
0.014\end{array}$ & $\begin{array}{c}456 \\
0.009\end{array}$ & $\begin{array}{c}463 \\
0.016\end{array}$ & $\begin{array}{c}453 \\
0.016\end{array}$ & $\begin{array}{c}467 \\
0.022\end{array}$ & $\begin{array}{c}457 \\
0.031\end{array}$ \\
\hline
\end{tabular}

Note: Regression coefficients shown with robust standard errors in parentheses. Models are first difference regressions where the dependent variable is the change satisfaction with local policy, change in trust in local authorities, change in democratic performance evaluations from before to after the referendum. Sign.: $* p<0.05, * * p<0.01, * * * p<0.001$. 